International Journal of Linguistics, Literature and Culture
Available online at https://sloap.org/journals/index.php/ijllc/
Vol. 7, No. 3, May 2021, pages: 180-187
$\begin{aligned} & \text { ISSN: 2455-8028 } \\ & \text { https://doi.org/10.21744/ijllc.v7n3.1623 }\end{aligned}$

\title{
Artistic Language of Ihara Saikaku
}

Gulnorakhon Bakhtiyorjon qizi Qosimova ${ }^{\text {a }}$

Article history:

Submitted: 9 February 2021

Revised: 18 March 2021

Accepted: 27 April 2021

\section{Abstract}

The paper is devoted to the analysis of Ihara Saikaku's artistic language as a novelist of the Japanese literature of Genroku period. Through the lingvopoetic analysis the author illustrates characteristic features of Saikaku's unique language.

\section{Keywords:}

artistic language;

early modern literature;

genroku period;

ihara saikaku;

japanese literature;

International journal of linguistics, literature and culture $(2) 2021$.

This is an open access article under the CC BY-NC-ND license (https://creativecommons.org/licenses/by-nc-nd/4.0/).

\section{Corresponding author:}

Qosimova, G. B. Q.

Department of foreign Eastern countries literature and comparative literature, Tashkent State University of Oriental Studies, Republic of Uzbekistan

Email address: nora.blackandwhite2012@yandex.ru

a Department of foreign Eastern countries literature and comparative literature, Tashkent State University of Oriental Studies, Republic of Uzbekistan 


\section{Introduction}

Ihara Saikaku (1642-1693) is one of the greatest writers of Japanese literature. The master of novellas, Saikaku, who in his works embodied the unique, new artistic ideas about the world and the place of man in the 17th century, remained in Japanese literature as the founder of realistic ukiyozoshi prose. Writer's works are distinguished by their diversity. In the first stage of his 12 year career as a writer, Saikaku wrote about the romantic life of the townspeople and created "koshokumono" - "books about love" and in the middle stage described the ideals among samurai, together with the vendettas of the warrior class through his "books about samurai" - "bukemono". In the final stage, publishing his "choninmono" - "books about townspeople" Saikaku turned his attention to the economic and social life of the middle-class townspeople. A few Saikaku's works that differ in genre, such as fantastic and detective novellas, novellas in epistolary form, travelogue lie outside this pattern, which represents a valid outline of his changing interests and changing personality during twelve years of his live as a novelist (Barna \& Androne, 2012; Chaika, 1977). Saikaku remained in the Japanese literature as an innovative writer who was able to create new, realistic fiction on the basis of traditions of classical literature. Like any representative of literature, when researching Ihara Saikaku's works from the point of view of tradition and innovation, it is impossible to fully achieve the set goal without learning his artistic language. However, before it, it is advisable to clarify the issue of his creative method. Because the method is a main factor in determining the language of any writer.

\section{Materials and Methods}

In order to reveal the characteristic features of Saikaku's language passages from writer's works such as "Koshoku ichidai otoko" ("The Life of an Amorous Man", 1682), "Nihon eitaigura" ("The Eternal Storehouse of Japan", 1688), "Seken mune zanyo" ("This Scheming World", 1692), "Saikaku oridome” ("Some Final Words of Advice”, 1694) were analyzed relying on the lingo-poetical method.

\section{Results and Discussions}

The attitude towards objective reality, which has been used since the medieval periods under the term "ukiyo", has changed over the Genroku (1688-1704) period. The direction indicated by Saikaku was expressed by the term "ukiyo", which means "this world", and for him the worldly life was the real life. Saikaku, who considered the world not a "sorrowful world" but a world of human activity, called on people not to give up this world, but to turn to it actively (Konrad:1972, p. 356).

In Saikaku's work, the realization of the value of worldly life and its reality, and the fact that man is the owner of his own destiny, served as an important basis for the formation of new principles of artistic assimilation of reality. The writer's steadfast adherence to the realities of his time led to the emergence of creative inspiration not from the ideal ready-made pattern known to reality, but from itself. Saikaku tried to describe life as it was. The pursuit of everyday reality of creative thinking broadened the possible boundaries of literature and enriched it with new themes, characters and conflicts (Flöel et al., 2005; Kaub et al., 2016).

Success in business and the prevention of bankrupt, as well as romantic adventures on red light districts and merchants love affairs have become full-fledged plots of literature (Pinus: 1969, p. 308). The frugal fathers of the family and the skillful devotees of love, the pure-hearted girls and the immoral young men, the industrious artisans and the sharp-witted rulers - the whole colorful world of early modern cities were on the threshold of literature. The traditions, psychology and daily life of townspeople, their struggle for the spiritual world and personal freedom served as material for the writer's novellas. Aspects of everyday life and human behavior, which were left out in the poetics of medieval Japanese literature, gained artistic significance in Saikaku's works and became aesthetically complete (Qasemireza \& Dowlatabadi, 2014; Smogorzewska, 2014). Striving to understand the life of the city and its inhabitants in full, together with its contradictions, to pay attention to the contradictions inherent in this life, to see its dark sides clearly are the testaments to the fact that the writer's works are based on the principles of a realistic approach to the depiction of reality.

The establishment of the principles of realism in the prose of Ihara Saikaku was an important innovation in his work, which laid the foundation for the emergence of non-qualitative methods of artistic generalization in

Qosimova, G. B. qizi. (2021). Artistic language of ihara saikaku. International Journal of Linguistics, Literature and

Culture, 7(3), 180-187.

https://doi.org/10.21744/ijllc.v7n3.1623 
comparison with the medieval periods. For Saikaku, worldly life was no more weak reflection of material superiority. Therefore, the writer relies on the logic of real reality to understand it. In describing the characters, actions and destinies of his characters, Saikaku always strives to be faithful to the realities of life. Whatever it is written about - the conflict of independent human emotions with the moral foundations of feudal society, the power of money that is steadily entering people's lives - the conflicts in the plot are always based on realism in his works.

Such a realistic prose of Saikaku is a unique phenomenon in terms of artistic language and style. In his work, he combined the literary language, which is widespread in the classical literature and vernacular language of townsmen of his time. Such combination of elements of tradition and the new era gave rise to a language now known as the 'language of Saikaku'. In order to give readers a clear and true picture of the real people of his time, the life of the townsmen, the writer skillfully used the lexicon of Genroku period, along with the words of the classical Japanese language. In particular, if we pay attention to the descriptive and narrative texts of Saikaku's novellas, dialogues or monologues of the characters, it is observed that they are filled with words and phrases, slangs, especially on the professions. For example, the author describes an artisan who repairs sheets or other household items with paper as follows:

「又表具屋の隙なる細工人と見えて、定木竹べらはけ糊迄を持てお座敷の腰張一間を一文、あかり障子一枚二文、 何行灯にても壹文にてさうぢまでいたしける。年徳棚を買ければ釣木釘まで持きたりて、恵方をあらため釣て歸ぬ。何にても 自由なる世時になりける。」(Suzuki: 1934, p. 70-71)

"After closing his workshop, he began to walk around the city, having with him everything he needed for work: a square, a bamboo spatula, a brush and glue. As for the payment, for the paper panels that are glued to the lower part of the wall in the living room, he took one ken, for repairing the shoji-two mons, and for the gluing of any lantern - one mon, and besides cleaned up all the trash after himself. Well, when someone bought a shelf for offerings to the New Year's god of fortune, he immediately arrived at the place, taking hinges and nails with him, and, having found out the right direction that was fortunate for a given year, in an instant he fitted the shelf."

Or, when talking about a poor and illiterate doctor, he writes as follows:

「門に嘐の声絶えて、内に神農掛絵も身ぶるひして、万の紙袋の書付ほこりに埋まれ、冬も羽二重のひとへ羽織、煎じ やう常にかはらぬ衣装つき、...」(Taniwaki: 1996, p. 60)

Voices at the gateway no longer announced the arrival of patients; whilst inside his house even the picture of Shinno, the patron of doctors, shivered with loneliness on his hanging scroll, and thousands of medicine packets and their inscriptions lay buried beneath the dust. Winter or summer Genko's physician's gown was the same unlined garment of habutae silk, the prescription for his own clothes never varying from "the mixture as before".

Saikaku, a merchant by profession, skillfully conveys the slang of masters of this profession with subtle irony. The dying merchant bids farewell to his family in a following way:

「我は行年六十三、定命さし引きなしに、浮世の帳面さらりと消して、閻魔の筆に付けかゆるに胸算用を極めければ、 何を思ひ残すことなし。」(Taniwaki: 1996, p. 90)

"I have lived for sixty-three years, and by normal standards that leaves no deficit. I have closed my account, and am ready to have the entries crossed from life's books and transferred by Enma to the books of Hades. I have no desire to stay.

Along with the indication through toponyms the places where the events take place, it is observed that to convey the national spirit and the atmosphere of daily life Saikaku used a lot of ethnographies such as the names of holidays and ceremonies, clothes and food, measurements and currencies, everyday household items. A number of words and phrases used in his works to express the realities of Genroku period are now included in the vocabulary of modern Japanese literary language, including 衣裳箪笉 “wardrobe”, 手拭 “towel”, 下駄 “geta” (Japanese wooden clogs), 足袋 “tabi” (Japanese split-toed socks), 風呂敷 “furoshiki” (traditional Japanese wrapping cloth) 看板 “signboard”手つけ(金) “deposit” 切売 “sel by the piece”, 計売 “sell by weight”, 手もちぶさた “have time on one's hands, have time to kill” 手土産 “present, gift”, 相場 “market”, 両替屋 “exchange counter”, 手形 “bill (of exchange)" (Sugimoto: 2012, p. 80).

Continuing the analysis of the Saikaku's language, it should be noted that the literary text of the writer is distinguished not only by the new words of the period, but also by the fact that the words of the past literary language are used in a unique way, in a new context. At this point, let us consider this aspect of the writer's work in the example of the word されば (sareba), which is often found in his novellas: 
この男、一生のうち草履の鼻諸を踏みきらず、釘のかしらに袖をかけて破らず万に気を付けて、その 身一代に二千貫目しこためて、行年八十八歳、世の人あやかり物とて桝掻きをきらせける。さらばかぎり ある命、この親仁、その年の時雨ふる頃、...頓死の枕に残る男子一人して (Taniwaki: 1996, p. 28)

Not once in his whole career did he wear out the thong of a sandal, nor tear a sleeve by catching it on the head of a nail, and as a result of this constant attention to the smallest of details he collected in a single lifetime the great sum of two thousand kanme. When he reached the auspicious age of eighty-eight he became the envy of his neighborhood and people begged bamboo grain-levels from him that they might share his luck. But, life has its limit, and that very year, when the rains of the tenth month were falling, ...leaving after himself a son the old man passed quietly away.

伊勢の社...何の偽りなき心を鏡に懸けて人も雲らず、殊勝に有難く、この秋津洲に住む者歩みをはこ びぬ。さればいづれの世より、小覚らしく宮廻りの蒔銭に鳩の目と云ふをかしげなる鉛銭、百というて 六十つなぎにして... (Taniwaki: 1996, p. 125-127)

Shrines in Ise... in the hearts of the deities themselves, as in their crystal mirrors, there is no trace of deceit. In the attendants' hearts too there is nothing but innocence and purity; and it is in this knowledge that people from every quarter of our Land of Autumn Harvests make the pilgrimage to Ise. But who, one wonders, was the pettyminded genius who started the custom of "pigeons" eyes those curious lead zeni which are sold to pilgrims, sixty on a "hundred string".

Relying on the context, we can be sure that the word "sareba" which is translated as "thus" or "that's why" is used in an unusual way, instead of the conjunction「ただし」 "but” in these passages.

Introductory phrase さる程に (saruhodoni), which means "along with it", is another example and is given in the author's text as follows:

兔角老いたる人の指図をもる〉事なかれ。何程利発才覚にしても、若き人には三五の十八、ばらりと 違うこと数々なり。さる程に大坂の大節季よろず宝の市ぞかし。(Taniwaki: 1996, p. 352-353)

It is better to take the advice of the old veterans. No matter how talented a young man may be, it often happens that in the end his advance calculations are completely frustrated. Now in Osaka the year-end scene resembles nothing so much as a treasure mart.

よく々見れば、隠居の尋ねらるる年玉銀にまぎれなし。「人の盗まめ物は出まするぞ。さるほどに憎い鼠め」といへば、

...(Taniwaki: 1996, p. 362)

When they looked closely, wrapped in a package this money was the very money the old woman was looking for. "What was never stolen is bound to turn up sooner or later. My! What a mischievous mouse that was!" they said...

This word also lost its original meaning in the text and was used by the writer to move from one subject to another in such a way that, as in the first example, it is impossible to give its exact translation. There is a similar situation in the next passage, which mainly serves to convey the emotion of the characters. The meaning that conveys the sentence will be more correct when the word is conditionally translated as "what a".

When Saikaku's works are read carefully, the idea naturally arises that these cases are a style peculiar to that period in the use of words. Therefore, such experiences of the writer in relation to the Japanese classical language should not be considered as a denial of traditions, but as an attempt to creatively renew the art of speech in harmony with the period.

In this regard, Saikaku's efforts to create new words and phrases should also be noted. In the following sentences we can find writers several new words that were formed from already existing words: 「あはうさ哀れさ悲しさ虚さ、折節は誠さも稀に、...」 “Foolishness, unhappiness, sadness, emptiness, sometimes sincerity is rare, ...", 「皮癬なほりて末だ間もなき手を打懸けらる、も喜し悲しくありける、...」“When the itching subsided, and finally when he lowered his hand a little, he felt a mixed feeling of joy and pain ...", 「十月十二日の月雪もあらはに野辺も見えわたり、...」“The moon of the twelve of December was also seen from the open valley...”「此紫堪忍ならずと果たし眼にて腹立、...」“After Murasaki was exhausted, he became angry with his eyes ready to kill, ...."

In particular, in the first example, Saikaku added the suffix 「さ」 (sa) to the words「虚」(empty) and 「誠」 (sincerity), that usually do not take this suffix, to enhance the tone of the sentence. The words $「$ 喜し悲しく」“joy mixed with pain”「月雪」 “winter moon”「果たし眼」 “eyes ready to kill” were the result of the use of the method of combining words that are common in haikai poetry.

Qosimova, G. B. qizi. (2021). Artistic language of ihara saikaku. International Journal of Linguistics, Literature and Culture, 7(3), 180-187. https://doi.org/10.21744/ijllc.v7n3.1623 
The texts of Saikaku's works are unusual phenomenon not only morphologically but also syntactically. His unusually long sentences (sometimes running for a page or more) are composed of uniformly short phrases. Here we clearly see the influence of haikai; especially haikai no renga poetry, which is formed from the connection of a number of verses. The outstanding characteristic of the language is its terse, elliptical quality known in Japan as the shöryaku (abbreviated) style. Saikaku not only omits all unnecessary words from within the sentence (and frequently some that seem very necessary), but he will very rarely provide transitional words or phrases between one sentence and the next. Here we try to analyze Saikaku's text through the excerpt from "Koshoku ichidai otoko" ("The Life of an Amorous Man") completing the omitted words:

貨物取に、長崎（へ下る人に）、我がも跡よりのおもひ立ちあるのよし（語りて）銀籍さきへ、預け て遺はし侍る。（その人）何か唐物（の買入れ）御望みあそばし、（て、この金をお下しなされと）候（ か）と尋ければ、(此)日本物を、買べきなげ銀と仰られける。さては丸山の御遊山計の御こころざしあり や、まなく、（お下りあらんを）あれにてまちたてまつるのよし（申しける。）(その日)六月十四日、け ふは都の詠め（をさめと）のこす月鉾のわたる時、我は玉鉾の商ひの道、いそぐて、（その人は）先立め 。 (Teruoka: 1996, p. 242-243)

(He) took the the box of gold coins, handed it (to a person who was going to) Nagasaki (and said): "I shall follow you there" When (the man) asked if (Yonosuke) wanted (to buy) foreign goods, he replied, "It is money to buy something Japanese." Maybe, you're just looking something from Maruyama's gay quarters? Then I will wait for you there." (And so the man) set out for the southern port city where foreigners dwelled. (It was) on the fourteenth day of the sixth month, a day on which a festival began, and his heart was torn between longing for the moon over the gay Gion quarters, which he was leaving behind, and the lure of material gain that had beckoned him on to Nagasaki, which after all proved the stronger.

When the above text, omitted by the author, is conditionally analyzed and supplemented by the words expressed in bracket, the complex sentences become understandable, at the same time simple. However, in many cases the text loses its original form if we complement it from such a logical point of view and grammatically correct it in order to convey the meaning to the reader.

This aspect of the writer's style, which emerged as a result of his work in poetry, can be explained by the fact that he created his prose works with the high speed as his haikai verses [7, 43]. Despite the economy of the words, the text of the novellas and artistic language of the writer, who can express the meaning that is usually conveyed in a few sentences in two or three words is generally reminiscent of a rich patterned fabric. In this regard, Saikaku called himself a "Naniwian weaver", comparing the profession or writers to the art of fabric weaving.

Saikaku's language is filled with proverbs and saying especially used by merchants in everyday speech, such as

「信心は徳の余り」 “The faith is a rest of the virtue” (Taniwaki: 1996, p. 64), 「買うての幸い、売っての幸せ」 “The joy of the buyer is the success of the seller” (Taniwaki: 1996, p. 70),「十人よれば十国の者」 “Ten people from ten countries” (Taniwaki: 1996, p. 78), 「問屋長者に似て、卵に似たり」“The wholesaler is like a rich man, like an egg” (Taniwaki: 1996, p. 79), 「生き馬の目は抜く」 “Stealing the eye of a living horse” (Taniwaki: 1996, p. 41), 「尻も結ばぬ糸のごとく」 “Like a thread with untied ends”, 「針を蔵に積みても溜まらぬ」 “Even if a warehouse is filled with money like a needle, it will not get full” (Taniwaki: 1996, p. 102) or with following songs like「やろか信濃の雪国を...」 “Let's go to Shinano, a snow country ...” (Munemasa: 1996, p. 91), 「相生の松風...」 “The winds in the ancient pines ...” (Munemasa: 1996, p. 62), 「月額剃って髪結うて...」 “Shaving your head in a half-moon shape” (Taniwaki: 1996, p. 376)，「なげきながらも月日を送り...」“Months and days past in a sorrow” (Taniwaki: 1996, p. 379)，「雪こん々や、丸雪こん々...」 “Snow is sprinkling, hail is sprinkling” (Munemasa: 1996, p. 189) that were popular among writer's time.

While examples of this folklore are often included directly in the literary text, excerpts from classic works are always quoted in a humorous quotation marks or given as allusions. For example, passage 「その物に付きて、その物をつひやし損ふ物、数を知らずあり。身に䖵あり。家に鼠あり。国に賊あり。 小人に財あり。君子に仁義あり。僧に法あり。」 (Yasuraoka: 1968, p. 416) “There are endless examples of something that attaches itself to another, eats away at it and harms it. A body has fleas. A house has rats. A nation has robbers. A lesser man has wealth. An honorable man has moral imperatives. A monk has the Buddhist Law." from the work of the writer Yoshida Kenko (1283-1350) "Tsurezuregusa" ("Essays in idleness", 1330/32) is parodied in Saikaku's novella about widow as allows 用心し給へ、国に盗賊、家に鼠、後家に入婿いそぐまじきことなり」 (Taniwaki: 1996, p. 43) Take care! 
Kingdoms are destroyed by bandits, houses by rats, and widows by suitors. Marriages are not matters for haste. In another novella, after description of a house full of cockroaches in front of alcohol shop, the same passage is referred to in a humorous tone:

古人も是をしらば、『家に油むし国に酒の酔』と書くべし (Suzuki: 1934, p. 78)

"When an old man found out about this situation, he would have written, "The cockroaches in the house are like the pianists in the country".'

Introducing a familiar image to a literary text, Saikaku often places it in an unexpected context, taking it "to the lowest point of everyday life" gives a new meaning to the whole work.

Describing the street scenery where the vegetable shops in Edo are located, the writer compares the row of baskets full of peppers to the autumn landscape of Mount Tatsuta, which is covered with a crimson maple leaves that is often mentioned in poetry: 「半切にうつしならべたる唐がらしは、秋ふかき竜田山を、むさし野に見るに似たり」 (Taniwaki: 1996, p. 471) "If you look at the rows of red peppers in the baskets, it's as if you're looking at the beautiful Mount Tatsuta from the Musashi". The same situation can be noticed in the next example: 「伝馬町のつみ綿、みよしのの雪のあけぼのの山々」 (Taniwaki: 1996, p. 471) “The cotton on Tenmacho Street could be mistaken for Ishino's mountains covered with snow in the morning."

While repeating another sentence by Kenko Yoshida, the writer continues: 「人の家にありたきは梅・桜・松・楓、それよりは金銀米銭ぞかし。庭山にまさりて庭蔵の詠め、...」

(Taniwaki: 1996, p. 60) "The things which best suit private houses, it has been said, are plum, cherry, pine, and maple - but what of gold, silver, rice and zeni? A garden landscape is a charming still is a row of garden storesheds..."

The sharpness of the side-by-side expression of these two ideas, or the stylistic dissonances that resulted from the comparison of classical literature and images of ordinary everyday life, as in the above examples, are the most important aspect of the writer's style.

Just as Saikaku's poetry strives for his prose, so does his prose. Unique methods of haikai - the game of homonyms - "kakekotoba", the chain of words and images selected by associations - "engo" - were deeply ingrained in his works. In particular, the writer concludes one of his novellas about the prosperous townsman, which was successful in business, based on the method of kakekotoba:

「この金の息よりは、機千万歳楽と祝へり」(Taniwaki: 1996, p. 27)

By interest alone such money grows to tens on tens of thousands

The phrase 幾千万歳楽 (ikusenmanzairaku) in this sentence means "how many thousands and thousands of silver can be prosperous", as well as the name of a Japanese congratulatory song and dance, "manzairaku", which is performed before person's house to wish him long life and prosperity. Therefore, the sentence can be translated as "Its voices swell in silvery songs to sing its lord's posterity ten thousand years of luck".

In

the

next

passage

「はやこの寒さわすれて、風をいとはぬかさね小袖、雨降って地かたまると、長柄のさしかけ卒に...」

(Taniwaki: 1996, p. 198) "He quickly forgot about the cold, ignored the wind, and put on a shortsleeve light coat, as they say, 'When it rains, the soil hardens" he held a long umbrella ..." the writer conveys after state of a merchant who got after bankrupt, forming an associative chain of images of "cold(ness) - wind - rain - umbrella" as in classical poetry.

\section{Conclusion}

Formed on the basis of traditions, Saikaku's innovative language is characterized by a combination of classical literary and vernacular languages of his time. Saturation with jargons, slang words according to the professions, toponyms, ethnographies, proverbs, sayings and folk songs, usage of words from classical literature with a new meaning or creation of completely new words on the basis of the old ones, laconicism and its elliptical quality can be noted as the distinctive features of Saikaku's artistic language. Saikaku's innovation in literary language is marked by the fact that he was the first who skillfully used the new words of colloquial language of Genroku period in the literature, having contributed to the enrichment of modern literary language. The relationship between tradition and innovation in the Saikaku's language is evident in the literary precedents in the form of quotations and allusions interpreted with irony or humor, which play an important role in the artistic system of the writer's work, in the

Qosimova, G. B. qizi. (2021). Artistic language of ihara saikaku. International Journal of Linguistics, Literature and Culture, 7(3), 180-187. 
stylistic dissonances resulted from the comparison of images from classical literature and everyday life. In Saikaku's artistic style, the influence of haikai poetry, which has inherited the methods of classical poetry, is strongly felt. In particular, from the sentences in the work to the plot construction, the writer relies on association-based rhetorical techniques such as engo, kakekotoba.

\section{Conflict of interest statement}

The author declared that (s)he has no competing interest.

Statement of authorship

The author has a responsibility for the conception and design of the study. The author has approved the final article.

Acknowledgments

I am grateful to two anonymous reviewers for their valuable comments on the earlier version of this paper. 


\section{References}

Barna, I., \& Androne, M. (2012). The language of literary texts-between artistic philosophy and cognitive-behavioral therapy. Procedia-Social and Behavioral Sciences, 51, 268-272. https://doi.org/10.1016/j.sbspro.2012.08.157

Chaika, E. O. (1977). Schizophrenic speech, slips of the tongue, and jargonaphasia: A reply to Fromkin and to Lecours and Vanier-Clément. Brain and Language, 4(3), 464-475. https://doi.org/10.1016/0093-934X(77)900384

Flöel, A., Buyx, A., Breitenstein, C., Lohmann, H., \& Knecht, S. (2005). Hemispheric lateralization of spatial attention in right-and left-hemispheric language dominance. Behavioural brain research, 158(2), 269-275. https://doi.org/10.1016/j.bbr.2004.09.016

Kaub, K., Karbach, J., Spinath, F. M., \& Brünken, R. (2016). Person-job fit in the field of teacher education-An analysis of vocational interests and requirements among novice and professional science and language teachers. Teaching and teacher education, 55, 217-227. https://doi.org/10.1016/j.tate.2016.01.010

Keene D. (1978) World within Walls. Japanese Literature of the Pre-Modern Era 1600 - 1867. N.Y. - 606 p.

Konrad N. (1972) Zapad i vostok [The West and the East] Moscow. - 496 р. (Конрад Н.И. Запад и Восток. М., 1972. -496 c.)

Morris I. (1969) The Life of an Amorous Woman and Other Writings (UNESCO Collection of Representative Literary Works). New Directions Publishing. - 403 p.

Munemasa I., Teruoka Y., Matsuda O. (1996) Shin Nihon koten bungaku zenshyu (67) Ihara Sakikaku shyu (2) [New full edition of Japanese classical literature. Vol. 67. Collection of Ihara Saikaku works (2)] - Tokyo: Shogakukan. 622 p. (宗政 五十緒・暉峻 康隆・松田 修「新編日本古典文学全集 (67) 井原西鶴集 (2) 」(小学館、1996))

Pinus Y. (1969) Chelovek v staroy yaponskoy literature. - Teoreticheskie problemi vostochnih literatur. [A man in the old Japanese literature. - Theoretical problems of Eastern literatures] Moscow. - 303-309 pp. (Пинус E.M. Человек в старой японской литературе - Теоретические проблемы восточных литератур. М., 1969. - 303309 с.)

Qasemireza, V., \& Dowlatabadi, H. (2014). Sociolinguistic Structure of Artistic Language; with Emphasis on Nader and Simin-a Separation. Procedia-Social and Behavioral Sciences, 98, 1428-1437. https://doi.org/10.1016/j.sbspro.2014.03.562

Shirane H., Suzuki T., Lurie D. (2016) The Cambridge History of Japanese Literature. Cambridge University P. 868 p.

Smogorzewska, J. (2014). Developing children's language creativity through telling stories-An experimental study. Thinking Skills and Creativity, 13, 20-31. https://doi.org/10.1016/j.tsc.2014.02.005

Sugimoto T. (2012) Saikaku to Nihongo no sekai: kotoba no ukiyoeshi [Saikaku and the world of Japanese language: ukiyo painter of words] - Tokyo: Sairyusha. - 481 p.(杉本つとむ「井原西鶴と日本語の世界: ことばの浮世絵師」(彩流社,2012） )

Suzuki T. (1934) Oridome: shinchyu [Oridome: new annotation] Okura kobundo. - 129 p. (井原西鶴 (著)・鈴木敏也 (翻訳) （1934）「織留: 新註」(大倉広文堂.))

Taniwaki M., Shinbo K., Gunji K. (1996) Ihara Saikaku shu 3 (Nihon eitaigura, Yorozu no fumihougu, Seken mune sanyo, Saikaku okimiyage [Collection of Ihara Saikaku works Vol. 3. Eternal Storehouse of Japan, An Old letter scrapbook, This Scheming World, Saikaku's Parting Gift.] Tokyo, Shogakukan. 638 p. (谷脇理史氏·神保 五弥·暉峻 康隆「井原西鶴集(3)日本永代蔵、万の文反古、世間胸算用、西鶴置土産」(小学館、1996))

Teruoka Y., Higashi A. (1996) Shin Nihon koten bungaku zenshyu (66) Ihara Sakikaku shyu (1) [New full edition of Japanese classical literature. Vol. 66. Collection of Ihara Saikaku works (1)] - Tokyo: Shogakukan. 606 p. (井原西鶴 (著)・暉峻康隆·東明雅 (翻訳)（1996）「新編日本古典文学全集 (66) 井原西鶴集 (1)」(小学館.))

Yasuraoka K. (1968) Tsurezuregusa zen chyushyaku [Full annotation of Tsurezuregusa] - Kadokawa shyoten. - 715 p. (安良岡 康作 (1968)「徒然草全注釈 下巻」(角川書店))

Qosimova, G. B. qizi. (2021). Artistic language of ihara saikaku. International Journal of Linguistics, Literature and Culture, 7(3), 180-187. https://doi.org/10.21744/ijllc.v7n3.1623 